Ссылка: Бурденко Е.В. Проблемы и история валютной интервениии в Европе в период XIX-XX вв.// Социум: проблемьл, анализ, интерпретации: Сборник научных трудов. - М.: МПГУ, 2005. с.274-279.

http://elibrary.ru/item.asp?id=25021331

\title{
ПРОБЛЕМЫ И ИСТОРИЯ ВАЛЮТНОЙ ИНТЕРВЕНЦИИ В ЕВРОПЕ В ПЕРИОД ХІХ-ХХ ВВ
}

Бурденко Елена Викторовна - почетный работник высшего профессионального образования, кандидат экономических наук, доцент кафедры политической экономии Российского экономического университета им. Г.В. Плеханова,

ResearcherID: E-3369-2014

orcid.org/0000-0001-5073-5062

burdenko-ev@yandex.ru

\section{Аннотация}

В статье рассмотрен исторический аспект создания валютных союзов между европейскими странами.

Ключевые слова: валюта, Европейский союз, интеграция, история евро.

\section{THE PROBLEMS AND HISTORY OF FOREIGN EXCHANGE INTERVENTION IN EUROPE IN THE PERIOD OF XIX-XX CENTURIES}

Burdenko, Elena V. - honorary worker of higher professional education, $\mathrm{PhD}$, Assistant Professor of the Department for Political Economy of the Plekhanov Russian University of Economics, ResearcherID: E-3369-2014 orcid.org/0000-0001-5073-5062 burdenko-ev@yandex.ru

\footnotetext{
Abstract

The article considers the historical aspect of the creation of monetary unions between European countries.
}

Keywords: currency, European Union, integration, the history of the Euro. 


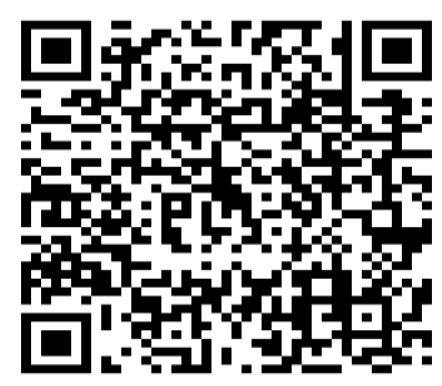

\title{
ПРОБЛЕМЫ И ИСТОРИЯ ВАЛЮТНОЙ ИНТЕРВЕНЦИИ В ЕВРОПЕ В ПЕРИОД ХІХ-ХХ ВВ
}

\author{
Бурденко Е.В. к.э.н., Российская экономическая академия
}

\section{им. Г.В. Плеханова}

Попытки создания валютных союзов между различными европейскими государствами неоднократно предпринимались в XIX - начале XX вв. В то время денежные системы и международные финансовые отношения были основаны на золоте и серебре. Проблемы с инфляцией возникали только при открытии новых крупных месторождений этих драгоценных металлов. Денежная политика и центральные банки ещё находились в процессе становления и мало сопоставимы с современными. Тем не менее, прошлый опыт представляет определенный интерес и сегодня.

Первым валютным союзом в Европе был Австро-германский валютный союз (1857-1866 гг.). В 1857 г. Австрия заключила договор с членами Германского таможенного союза, по которому три различные валюты были связаны вместе условленным постоянным обменным курсом и общей единицей учёта. Однако выпуск единых денег вместо национальных валют не предполагался. Не было наднационального органа или метода выработки соглашений для урегулирования спорных вопросов в случаях, когда одна из сторон не выполняла взятых на себя обязательств. При отсутствии реальной интеграции банковской и денежной систем союз оставался формальным обязательством поддерживать условленные обменные курсы. В 1866 г. политический конфликт между Австрией и Пруссией перерос в войну и союз распался. 
По инициативе Франции в 1865 г. был создан Латинский валютный союз (1865-1878 гг.), в который вошли Франция, Бельгия, Италия и Швейцария. Франция играла в нём доминирующую роль. Три остальные страны ко времени создания союза приняли французский биметаллический стандарт с фиксированным соотношением между серебром и золотом, и база для валютной кооперации уже существовала. Целью договора было достижение единообразия чеканки монет, которые должны были взаимно приниматься национальными казначействами как законное платежное средство. Эмиссия ограничивалась в соответствии с формулой, основанной на относительном размере населения каждой страны.

Союз не мог быть успешным, так как не были учтены расширяющееся использование банкнот, о которых в договоре не упоминалось, а также временное падение стоимости серебра по отношению к золоту. В 1878 г. союз согласился приостановить чеканку серебряных монет, что фактически означало его конец, хотя формально он пережил первую мировую войну.

Скандинавский валютный союз (1875-1917 гг.) образовался в результате заключения соглашения между Данией, Норвегией и Швецией о выпуске одинаковых монет. Конвенция не содержала положений, касающихся обращения банкнот, хотя они уже широко использовались в этих странах. Тем не менее, их центральные банки вскоре начала принимать банкноты друг друга и пересылать их для кредитования текущего баланса, поддерживаемого каждым банком. Экономя на операциях с золотом и создав эффективный международный клиринговый ${ }^{1}$ механизм, союз успешно просуществовал до первой мировой войны.

Первая мировая война расстроила экономическую и финансовую системы скандинавских стран. Несоответствие структур цен в этих странах и значительный приток золота привели к разрушительным последствиям

\footnotetext{
${ }^{1}$ клиринговая валюта - валюта, применяемая при взаимных расчётах через счета в банках и при сделках между государствами
} 
для относительных обменных стоимостей их валют. В 1917г. страны перешли к использованию во взаимных операциях исключительно золота, что привело к краху союза.

Бельгийско-люксембургский экономический союз был учреждён в 1921г. Люксембургский франк был привязан к бельгийскому в отношении один к одному. Во время второй мировой войны оккупированный Люксембург стал частью немецкой валютной зоны, но пересмотренный в 1944 г. договор вновь подтвердил равную стоимость бельгийского и люксембургского франков. В 1981 г. более детализированное соглашение определило структуру дальнейшего валютного сотрудничества в рамках данной валютной ассоциации. Бельгийские банкноты и монеты являются законным средством платежа в Люксембурге, тогда как люксембургские банкноты и монеты не служат законным средством платежа в Бельгии, но могут быть обменяны без потерь на бельгийские. Внешняя стоимость ко всем остальным валютам у них одинаковая. Курсовая политика по отношению к валютам третьих стран проводится на основе взаимного соглашения. Несмотря на то, что экономические показатели свидетельствуют о различиях между этими странами, валютный союз действовал вплоть до введения евро, то есть около 80 лет.

\section{Предпосылки создания ЕВС}

Причины развития процессов валютной интеграции в ЕЭС неотделимы от структурных изменений в мировой капиталистической системе хозяйства и эволюции её валютных систем с начала 70-х годов.

В 50-х и начале 60-х годов Бреттонвудская валютная система была относительно стабильна, так как её механизм соответствовал структуре мирового капиталистического хозяйства и расстановке сил на международной арене. В 50-е годы экономическое могущество США

\footnotetext{
2 общепринятая аббревиатура Европейской валютной системы
} 
поставило все другие капиталистические государства в полную экономическую и финансовую зависимость.

Однако изменение соотношения сил в капиталистическом мире в пользу стран Западной Европы и Японии, рост их экономической мощи привели к выступлениям против валютной гегемонии США, которые злоупотребляли статусом доллара как резервной валюты, поощряя внешнеэкономическую экспансию американских монополий.

Непосредственный толчок планам создания ЕВС дали Ямайские соглашения о реформе международной валютной системы (1976-1978 гг.), основные принципы которой не отвечали интересам западноевропейских стран:

-страны ЕЭС не были удовлетворены функционированием системы СДР ${ }^{3}$ и её тесной связью с американским долларом;

-страны ЕЭС были недовольны введением плавающих курсов, отрицательно сказывающихся на их внешней торговле и функционировании уже созданных интеграционных процессов ЕЭС.

С 13 марта 1979 года начала функционировать Европейская Валютная Система в составе 8 стран «Общего ранка» (Германия, Франция, Бенилюкс ${ }^{4}$, Италия, Ирландия, Дания).

На сегодняшний день ЕЭС насчитывает 15 стран-участниц с суммарным населением в 377 миллионов человек и ВНП составляет 6 миллиардов евро, что на 10\% выше аналогичного показателя США и на 64\% выше Японии.

\footnotetext{
3 СДР представляет собой расчётную (виртуальную) валюту Международного валютного фонда (МВФ), именуемую как специальные права заимствований (Special Drawing Rights), которая в действительности не имеет материального воплощения и реального эквивалента, а применяется как резервный актив в дополнение к золотовалютным позициям стран-членов МВФ. Курс СДР как расчётной валюты МВФ в настоящее время определяется в 4-х валютах: долларах США, евро, английских фунтах стерлингов и в японских иенах, до 1999 г. исчислялся в 5-ти все указанные и немецкая марки, а ещё ранее - в 16-ти валютах

4 Бельгия, Нидерланды и Люксембург
} 


\section{Механизм работы ЕВС}

Механизм ЕВС образовывали три элемента:

- европейская валютная единица - ЭКЮ;

- $\quad$ режим совместного колебания валютных курсов - «суперзмея»,

- Европейский фонд валютного сотрудничества.

ЭКЮ - была составной валютой, её поддерживала корзина национальных валют стран Сообщества, причём доля каждого участника зависела от веса страны в совокупном валовом продукте и взаимной торговле. Квоты выглядели следующим образом:

• 32,7\% Немецкая марка

- 20,8\% Французский франк

• 11,2\% Английский фунт

$\bullet 10,2 \%$ Голландский гульден

• 7,2\% Итальянская лира

• 8,7\% Бельгийский и люксембурский франк

• 4,2\% Испанская песета

• 2,7\% Датская крона

• 1,1\% Ирландский фунт

$\bullet$ 0,7\% Португальское эскудо

$\bullet 0,5 \%$ Греческая драхма

Ежедневно определялось расхождение между рыночным и центральным курсами каждой валюты в ЭКЮ. Рыночный курс валюты мог достигнуть «порога» отклонений по отношению к ЭКЮ, не выйдя за пределы его допустимых колебаний по отношению к национальным валютам стран-участниц ЕВС. Этот «сигнальный» механизм был призван заранее предупреждать страны о приближающимся нарушении двусторонних соотношений валютных курсов. 
Действующий механизм обменных курсов стран ЕС ограничивал изменения валют в пределах $2,25 \%$ одна относительно другой и в диапазоне не более $15 \%$.

Сетка паритетов и её связь с ЭКЮ являлась основой валютных интервенций и системы взаимного кредитования и расчётов. Обычно интервенции проводятся одновременно банками стран, курсы валют которых достигли противоположных допустимых пределов взаимных отклонений. Банк сильной валюты покупает слабую валюту, а банк слабой валюты продаёт сильную. Однако покупка сильной валюты означает для страны со слабой валютой затрату валютных резервов, что вынуждает прибегать к ужесточению денежно-кредитной политики, повышению учётных ставок. Эта система даёт односторонние преимущества странам с сильной валютой.

Введение механизма поддержания валютных курсов и системы валютных интервенций повлекло за собой создание системы кратко- и среднесрочного кредитования, в которую входили следующие элементы:

1. Система кредитов типа «своп» между центральными банками, чьи курсы валют достигли допустимых пределов.

2. Фонд краткосрочного кредитования (14 млрд. ЭКЮ в 1985 году). Для каждой страны были определены величина взноса в этот фонд и объём допустимого кредита на срок от 3-х до 6-ти месяцев с правом продления до 9 месяцев.

3. Фонд предоставления среднесрочных кредитов на срок от 2 до 5 лет (в размере 11 млрд. ЭКЮ в 1985 году).

Краткосрочное кредитование проводилось центральным банком без какихлибо условий, а среднесрочные кредиты предоставлялись при условии проведения экономической политики, одобренной Советом Министров ЕЭС на уровне министров финансов.

Позднее, фонды краткосрочного и среднесрочного кредитования были преобразованы в Европейский Валютный Фонд, который заменил 
Европейский фонд валютного сотрудничества, созданный в 1973 году в период первой попытки сообщества достичь экономического и валютного союза.

В решении о создании ЕВС предусматривалось, что ЭКЮ станет:

1. основой для расчётов в рамках механизма, определяющего валютные курсы;

2. основой для определения показателя отклонений курса какой-либо из денежных единиц, входящих в эту систему от среднего показателя по странам-членам ЕЭС;

3. средством осуществления валютных интервенций, заключения сделок и предоставления кредитов;

4. средством расчётов между центральными банками стран-членов, а также между валютными органами ЕЭС;

5. реальным резервным активом.

В рамках ЕВС роль золота как резервного актива значительно повысилась: оно использовалось в качестве частичного обеспечения ЭКЮ, был создан крупный межгосударственный фонд золота. Страны ЕЭС обладали примерно 40\% мировых золотых запасов.

Главный недостаток ЭКЮ заключался в том, что основные факторы, воздействующие на объем эмиссии - цена на золото, курс доллара - не поддавались регулированию, что приводило к бесконтрольным колебаниям эмиссии в отрыве от реальной потребности в ЭКЮ, так как эмиссия ЭКЮ обеспечивалась на 50\% национальными валютами стран ЕЭС, а на 50\% 1/5 частью золотодолларовых резервов стран ЕЭС.

Нерешенным оставался вопрос о распределении ЭКЮ. Страны-члены получали ЭКЮ пропорционально их золотодолларовым резервам. Однако в рамках ЕВС стояла задача сглаживания региональных диспропорций и оказания помощи наименее развитым странам сообщества. В решение этой проблемы могло бы внести вклад распределение ЭКЮ на основе показателя национального дохода на душу населения. На практике это 
означало бы, что «богатые» страны должны безвозмездно передавать менее развитым странам часть своих денежных накоплений.

Многие из этих проблемы пытались решить с введение ЕВРО. ЛИТЕРАТУРА:

1. Булатов А.С. Экономика. - М.: изд. БЕК, 2001.

2. Валютное регулирование, Финансовый Бизнес. - 2002. - N17(45).

3. Валютный портфель. - М.: Прогресс, 2000.

4. Иванов И.Д. Единая валюта для интегрирующейся Европы/ Мировая экономика и международные отношения. - 2001. - N4.

5. Жуков Н.И. Из истории мировых валютных систем, ЭКО. - 1999. N9.

6. Круглов В.В. Основы международных валютно-финансовых и кредитных отношений. - М.: ИНФРА-М, 2001.

7. Петерсон Т. «ЕВРО» Бизнес Уик. - 2001. - N4.

8. Смыслов Д. Куда идет мировая валютная система/ Мировая экономика и международные отношения. - 2002. - N7, N8.

9. Восточная Европа готовится к встрече с евро/ Финансовые известия. $-2001-\mathrm{N} 22$.

10.Финансовая Россия - 2001 - N27.

11.Финансовые известия $-2002-\mathrm{N} 10$.

12.Подколзина И. Единая Европа: Эксперимент в реальном времени. МЭМО 2000 г.№8.

13.Крайний В. Валютный союз по-европейски/ - Интерфакс-АиФ. - 2001 №16

14.Глухарев Л.И. Европейские Сообщества: в поисках новой стратегии: - Москва. 2000 г.

15.Иванов И. Расширение Евросоюза: сценарий, проблемы, последствия: МЭМО №9 М. 1998 